\title{
ICT AS AN EDUCATION SUPPORT SYSTEM QUANTITATIVE CONTENT ANALYSIS BASED ON ARTICLES PUBLISHED IN EMI
}

\author{
Dr. Tünde Molnár Lengyel
}

\begin{abstract}
These days the European Union is forced to contend with a serious shortage of info-communication experts. According to the prediction of the European Commission in 2015 this sector will be lacking 900000 professionals. While annually more than 100000 jobs or employment opportunities are created by the ICT industry, there is a lag in relevant professionals." (Nemzetközi összefogás az it-s szakemberhiány ellen, 2013) Moreover, this trend is not only impacting Europe as in 200658000 work visas were available in America for ICT professionals. (McCormack, 2010) Although it has become clear that only education can provide an effective answer to the problem of the lack of professional experts, only business firms offer IT and ICT related training opportunities and higher education institutions do not provide programs aiming to meet relevant employer demands. Consequently, any improvement of the present situation requires a familiarity with the concept of ICT along with an overview of is history and continually increasing role in the education process.

Thus the present effort aims to answer the following questions: As a direct connection can be established between ICT and Information Technology, since when can ICT be considered as an educational tool? What did the conceptual system of ICT replace? How did ICT supersede the concept of Educational Technology? Can ICT be merely viewed as an all-round education tool, or there is more to its application?

"Educational tools or devices are objects, materials, instruments and technological equipment, facilitating the realization of pedagogical goals and vigorously promoting the school-based learning process, specific knowledge acquisition efforts and the direct (in some cases indirect) familiarization with reality via their capability of transmitting, recording, and storing information in an effective way." (Fodor, 2008)

Since when has ICT fulfilled such roles in the education process? "The application of information and communication technology in education primarily manifests itself in a cybernetic, system in addition to a communication theory based planning and organization strategy of the learning and information acquisition process guaranteeing the optimalization of the accessibility and the reception of information with the use of modern information carriers, methodologies, and technologies." (Kis-Tóth, 2008. p.3.)

The present research effort focused on the total spectrum of articles published in full textual form between 2000 and 2010 in the periodical titled Educational Media International. Frequency analysis or computerized content analysis, a branch of quantitative content analysis was the main research method. The main goal of the inquiry was not to perform a statistical analysis on the totality of expressions, rather an examination of the occurrence of such terms as "Information and Communication Technology," "Information Technology," "IT," and "ICT." Consequently, the research samples consist of the words of the text, or "mutually independent components of the source language flow." (Krippendorff, 1960, p.60)

The research effort includes the investigation of the textual context of the aforementioned terms via the standard keyword in context (KWIC) method providing a report on the terms:"Information and Communication Technology," "Information Technology," "IT," and "ICT."

It is expected that the research will facilitate the determination of the proliferation time of the given expression, which due to the unique nature of the respective periodical can be dated from the time when education started to provide a response to the challenge of technological development. The exploration of particular terms' textual surroundings can help in determining the origin of the given concept along with revealing the relevant previous and contemporary contextual background.
\end{abstract}

\section{KEYWORDS}

Educational Media International, EMI, Information and Communication Technology, Information and Communication Technology definition, Information Technology, IT, ICT, ICT definition 


\section{Justification, or the factors motivating the writing of this essay}

There is a strong need for expert ICT professionals both in Hungary and in the European Union. While in Hungary the ICT sector shows encouraging growth, the provision of appropriate human resources is a significant challenge.

According to economic indicators the future of ICT professionals appears to be bright in Hungary.

As far as the changes in the 2012 GDP are concerned an overall stagnation or performance decline can be discerned in virtually all aspects, with the exception of the information communication technology sector. Said results are all the more remarkable as they were achieved without government subsidies.

As the Information Department of the Hungarian Chamber of Commerce and Industry asserts the digital sector is a crucial component of business competitiveness in the $21^{\text {st }}$ century. Despite the overall recession the info-communication sector was capable of producing substantial growth along with displaying the strongest investment potential. Furthermore, the Hungarian info-communication sector is populated by small and medium sized domestic enterprises, thus the respective profits are realized in the country. (Budapesti Kereskedelmi és Iparkamara Hírközlési, Informatika osztályának állásfoglalása, 2013)

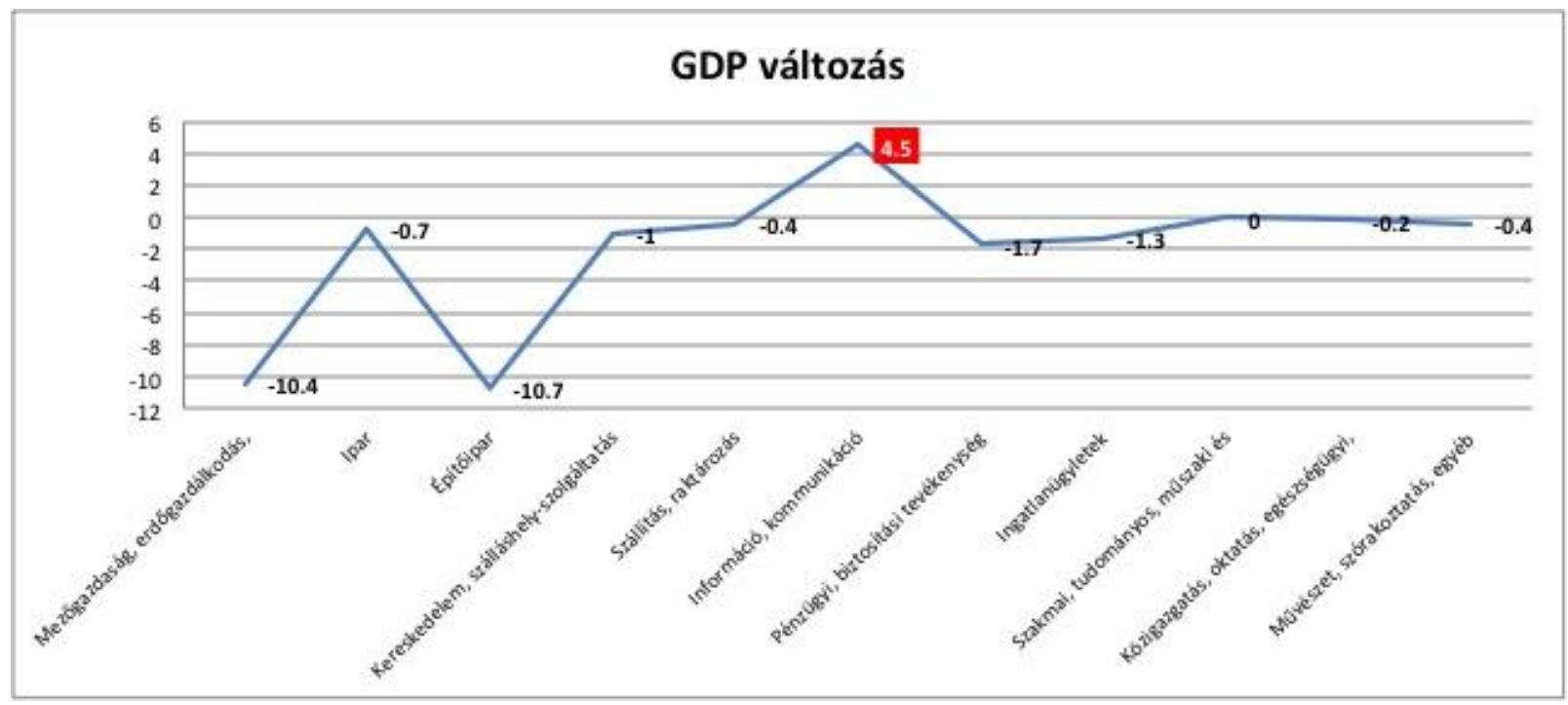

The fluctuation of the GDP in Hungary

In addition to the respective high performance figures achieved in 2012 the info-communication sector has significantly impacted both Hungarian economy and society. According to a source representing the Hungarian government the ICT industry provides $12 \%$ of the Hungarian GDP and the employment figures of this sector in comparison to most OECD countries are especially high. (Nemzeti Fejlesztési Minisztérium, Kommunikációs Főosztály, 2013) The National Info-Communication strategy compiled by the Ministry of National Development for the period between 2014-2020 warns of a potential lag: "Without a well-designed and precisely implemented plan aiming at the elimination of factors hindering further rapid development Hungary might not be able to take advantage of the full potential of its ICT sector and it is in danger of falling behind in the already very sharp competition in the European Union.

The European Union has assigned crucial priority to the development of the ICT sector in the past decade as reflected by the series of European level action plans. Consequently, the Hungarian government in 2009 has established a national strategy, which according to Mihály Varga, Minister of Economy aims at the promotion of competitiveness at the micro economic level via sector specific growth packages. (Kormányzati akcióterv az ikt-szektor támogatására, 2009) The complete program is geared towards the development of the knowledge-based economy entailing human resource development, the support of further and re-training programs and the promotion of investment. 
Since approximately half of the Hungarian population lacks basic ICT skills, such development promoting measures are more than justified. According to the report of the Hungarian Chamber of Commerce and Industry said lack of digital literacy entails a potential 197 billion forints or $0.74 \%$ GDP decrease, (Kormányzati akcióterv az ikt-szektor támogatására, 2009) symbolizing the digital gap between Hungary and the average level of the European Union.

In 2013 the Hungarian Chamber of Commerce and Industry requested the Hungarian government to support a separate Information and Communication Technology Operative Program in the 2014-2020 budgetary period especially prioritising the training of a highly qualified and experienced ICT labour force.

In my opinion the respective solution requires addressing the following two issues

1. Widening the variety of informatics training programs offered by the higher education sector

2. Increasing the role of ICT in education

\section{Promoting the diversity of informatics training schemes}

In his analysis of the range of information training schemes in Hungary Péter Dobay calls for the implementation of a new degree program. Traditional training programs offered by higher education institutions in Hungary have already incorporated international expectations, especially the so-called sample curricula. Such schemes on the one hand utilize experiences obtained both at the university and in the labour market including recommendations by noted professional organisations and enterprises, and show the way for the elaboration and implementation of new specializations, programs and educational materials on the other. However the increasingly complex and continuously changing information systems of the business sphere require training programs meeting such demands. (Dobay, 2010) Recently the labour market has shown a radical shift from prioritizing professional level developmental engineers to users with information management capabilities. (Dobay, 2010)

Current informatics training efforts in the Hungarian higher education arena specialize in training experts in the following fields:

- informatics technology

- program design

- business informatics

Consequently, due to the narrow scope of the training structure graduates of the given program can become experts only of their chosen field and have only a limited knowledge of other areas. Since presently no comprehensive training programs are available, informatics graduates wishing to widen their professional horizons need to partake in other training schemes.

One potential solution could be the so-called IT academies offered by leading representatives of the ICT field. Such gap-filling programs with different titles and length were implemented by the following firms

- CISCO,

- Microsoft,

- ORACLE,

- IBM,

- SAP

Nevertheless, higher education institutions should develop their own solutions as well. The university and college sector is required to produce graduates meeting the requirements of the ICT profession. Therefore ICT training opportunities should be offered in all MA/MSc level post-graduate and special further training programs. Naturally, these options cannot substitute the previously mentioned schemes. 


\section{The role of ICT in education}

According to the 2006 European Schoolnet Survey focusing on the impact of ICT in education in the OECD countries a positive correlation can be discerned between the extent of ICT use and the achievements in Mathematics as indicated by the Pisa Survey. Furthermore, it was shown that student achievement in schools well equipped with ICT devices is higher than those with a lower level of access to information technology. A survey in the 16 year age group revealed that students in classrooms equipped with wideband connections have achieved better results in national competitions as well. (Balanskat, Blamire \& Kefala, 2006)

Consequently, the Hungarian government aims at the re-consideration of the role of infocommunication in public education by 2020 both in case of informatics as a subject and in case of infocommunication as an attitude or perspective and a valuable device supporting the learning effort. (Nemzeti Infokommunikációs Stratégia 2014-2020, 2013)

The implementation of such program requires the clarification of the ICT conceptual system along with an overview of its potential application options. The rest of the study will focus on the respective definitions followed by a scholarly look at the development and textual occurrences of the concept in the professional journal titled Educational Media International.

\section{Defining the concept of ICT}

There are several definitions of the ICT concept!

According to the official terminology of the European Union ICT reflects the convergence and integration of information technology and electronic communication. (Nemzeti Infokommunikációs Stratégia 2014-2020, 2013)

According to its Hungarian adaptation info-communication entails all devices, technologies, and applications and their use facilitating an improvement in quality, efficiency, and productivity at the individual, enterprise, and government levels. (Nemzeti Infokommunikációs Stratégia 2014-2020, 2013)

Stefan Detschew (2007) defines the term in a more general sense: "ICT consist of the whole range of technologies designed to access, process and transmit information: hardware, software, networks, and media for collection, storage, processing transmission, and presentation of information in the form of voice, sound, data, text, and images. They range from the telephone, mobile phone, hardware, software to the Internet." (p. 28)

While the above definitions treat ICT both as a device and technology, or perhaps, an application, in order to emphasize its role in the support of the learning process, the concept has to be expanded. Where as the term ICT-based instruction or ICT supported instruction is gaining increasing popularity, the ICT adjective or prefix is indispensable to any definition. The complexity of the issue is reflected by György Molnár's (2009) definition: The concept of ICT entails the totality of devices, technologies, arrangements and innovative processes facilitating the information and communication process along with promoting the speed, ease, and efficiency of processing, storing, and coding of information in addition to ensuring an obstacle free information flow

Thus ICT can be regarded as

- a device

- a monitoring tool and automated technology

- an arrangement technology

- as media and related compatible technology

- a development process and a social engineering procedure

- as technological practice. (pp.3-4.) 
Molnár's (2008) interpretation highlights the capability of ICT superseding the term multimedia: ICT is a type of media facilitating several forms of interaction and communication including between machine to machine, human to machine and especially human to human.

Moreover, mention must be made that the most frequently used definitions follow Kar-Tin-Lee's (2006) general approach: "IT and ICT refer to the use of a range of computer-related technologies (hardware, software, communications and associated technologies) in an educational setting." (p. 104)

Finally, I would like to emphasize an ICT definition focusing on its capability of promoting the learning process.

Furthermore one should consider the connection between information technology and information communication technology. Does IT entail ICT? According to the most frequent answer given by researchers "Information technology (IT) is synonymous with the term information and communications technology (ICT) used in various other countries." (Kar-Tin, 2006, p. 104)

At the same time we can look back to the definition of a previously used term, Educational Technology, while keeping in mind that while the ICT concept appears compatible, the latter surpasses the instruction function:.

"Educational tools or devices are objects, materials, instruments and technological equipment, facilitating the realization of pedagogical goals and vigorously promoting the school-based learning process, specific knowledge acquisition efforts and the direct (in some cases indirect) familiarization with reality via their capability of transmitting, recording, and storing information in an effective way." (Fodor, 2008)

\section{The use of the ICT concept in the EMI journals}

My research effort included a quantitative content analysis of the following terms in the scholarly articles published in the Educational Media International: Communication Technology, Information Technology, IT, ICT. My inquiry focused on the texts of the given articles and did not include the cited professional literature.

The analysis has provided interesting results. The term ICT has appeared in professional texts since 1999 and its distribution is not even. A very frequent use can be discerned in 2007 and 2011 probably reflecting strategies mentioned at the beginning of the present essay. Moreover ICT was a crucial term in the 2007-20012 EU strategy as well.

\section{Occurrences of the term ICT}

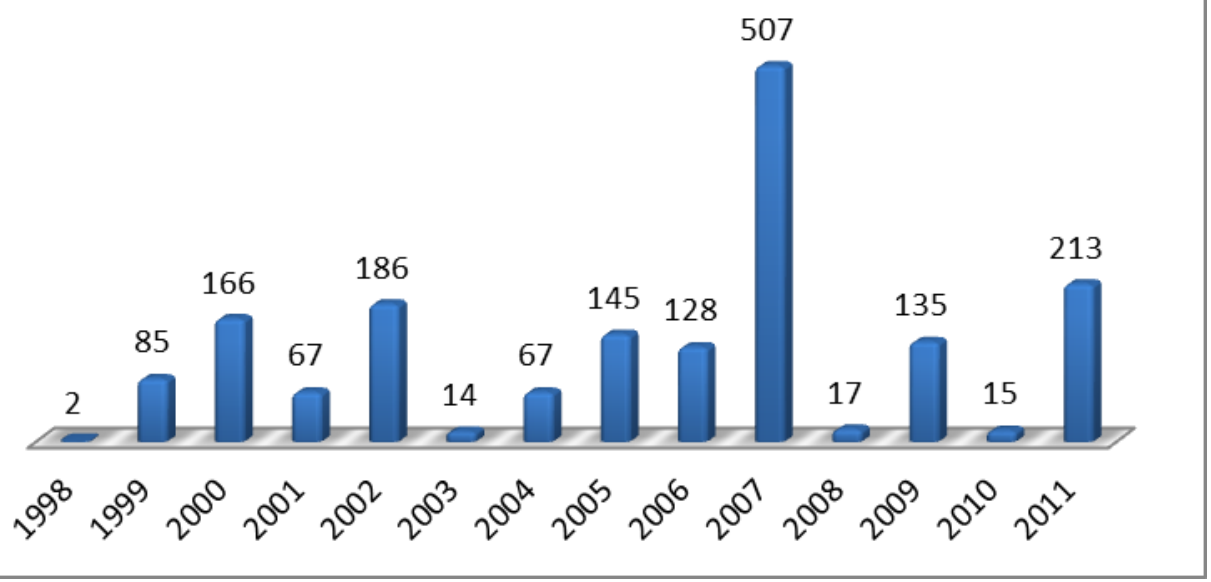


I have examined the occurrences of the terms Information and communication technology/technologies, and the respective graphs show virtually identical distribution compared to the previous one:

\section{Occurrences of the terms Information and communication technology/technologies}

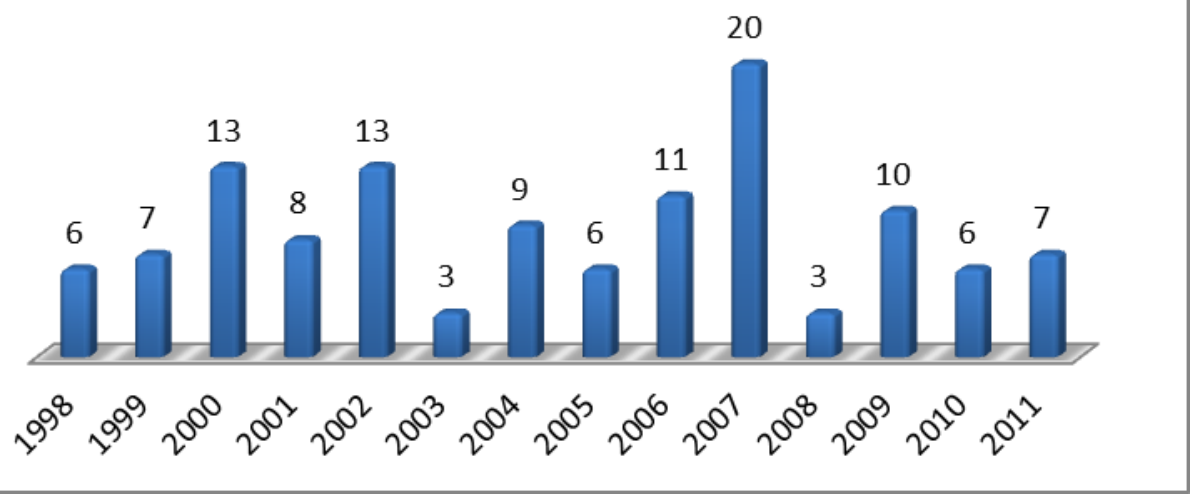

Occurrences of the terms Information and communication technology/technologies

If we expand our scope to include the given textual context we find that certain expressions are regularly used during the period in question:

- ICT integration

- ICT in education

- Use of ICT / ICT using

- ICT skills

- ICT in schools

- ICT competencies

Yet there are some coupling terms which are characteristics only in a given period:

Thus in 2007 ICT was coupled with these terms listed below

- ICT training

- ICT curriculum

- ICT centres

- ICT coordinators

- ICT-mediated learning

In 2011 the following terms were prevalent:

- ICT policy

- ICT school policy (the above two expressions have been used 20 times in articles published in 2011 as compared to two occasions in articles published before 2011)

- ICT infrastructure (While this expression can be found altogether 7 times between 1998 and 2010, 13 occurrences have been registered in articles published in 2011)

One possible explanation can be provided by the analysis of the surrounding verbal context as the latest EU strategy, the EU 2020 pertains to the 2014-2020 period, thus the respective terms are a constant component of discussions and implementation preparations

Our inquiry in the occurrence of the term IT reveals that it was a preferred term until the beginning of the first decade of the 21 st century. 


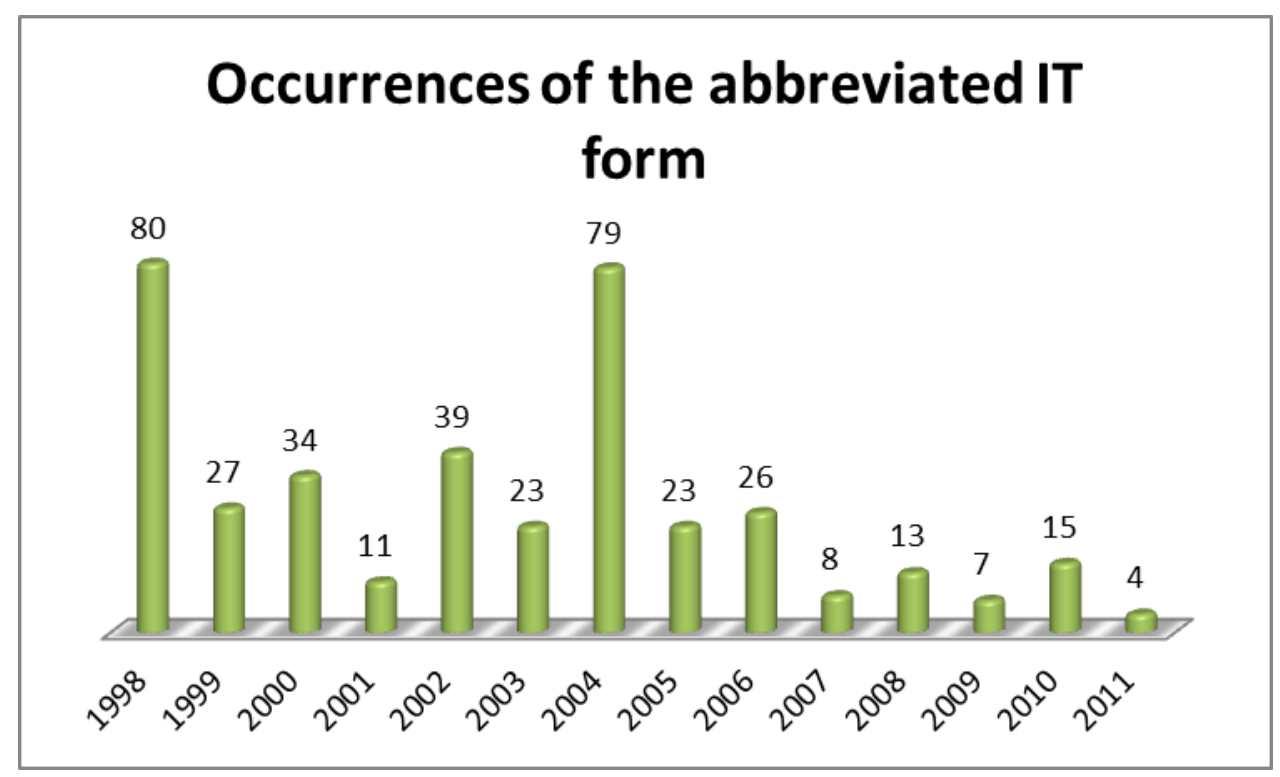

Occurrences of the abbreviated IT form

Its use begins to decline after 2004, which can be due to the proliferation of the term ICT. As compared to the frequency of the abbreviated form the use of the full expression shows a steady decline, but its pace is somewhat different to its abbreviated counterpart.

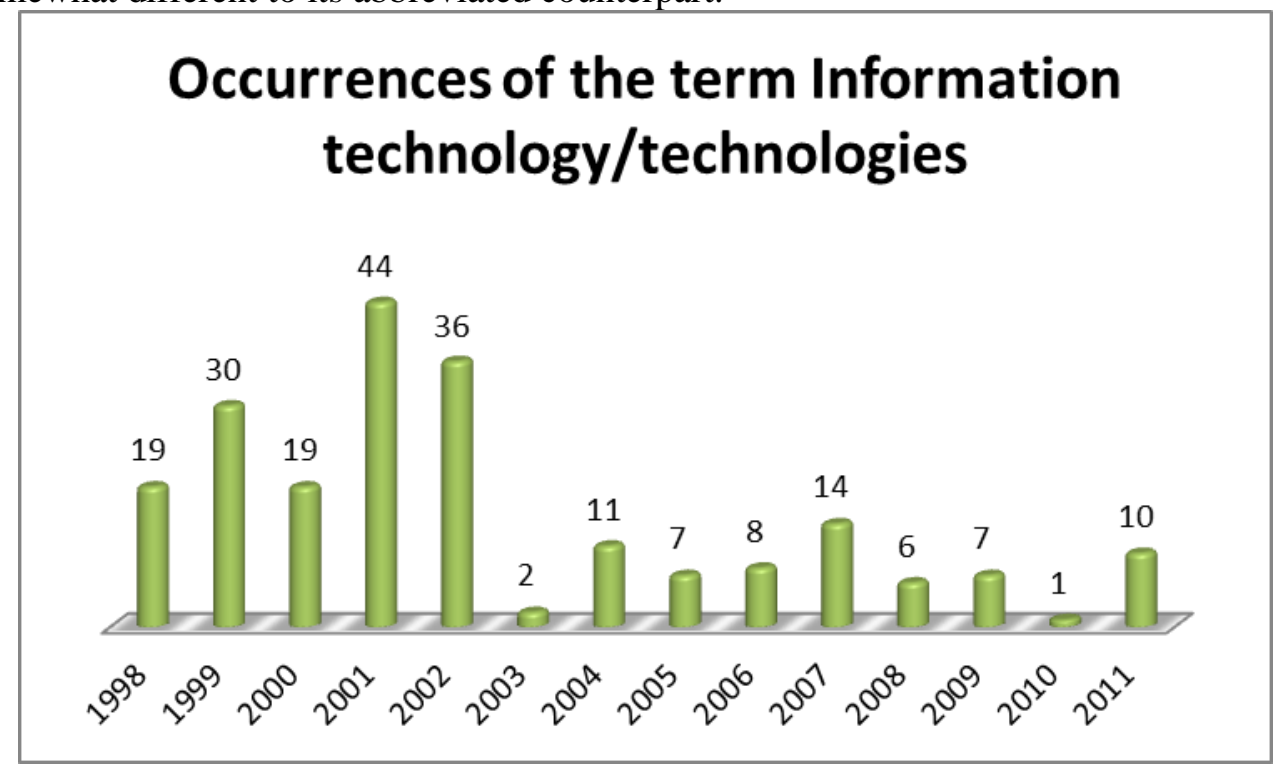

Occurrences of the term Information technology/technologies

The contextual analysis revealed the use of one more frequently used term, IT education, further highlighted by the abbreviation of ITE.

\section{Summary}

While the appearance of the term ICT can be traced back to the Millenium, the frequency of its occurrence related to the passage of time does not show an even paced growth, as it is used in an unsteady, fluctuating manner.

There is a clearly discernible decline in the use of the term IT.

Another essay should examine the reason why the use of the ICT concept did not increase exponentially. Additional efforts should identify if there is a better term reflecting technology supported education. In our research we encountered such terms as 
- internet (web-based) instruction [however, this is only one section of the field covered by the ICT concept]

- ICT-supported learning environment (this term is also sporadically used in an isolated manner)

The analysis, however, cannot correspond to the situation in Hungary as in our country the role of ICT is very significant. The guidelines and aspirations outlined at the beginning of this essay indicate a strong commitment towards the application of ICT reflecting the given EU strategies. The articles produced by the global research community and published in the Educational Media International do not reinforce the prevalence of ICT in the education process. This question is yet to provide a fruitful topic for further research.

\section{REFERENCES}

Balanskat, A. Bamire, R. \& Kefala, S. (2006) The ICT impact report. European Schoolnet, Retrieved from http://colccti.colfinder.org/sites/default/files/ict_impact_report_0.pdf

Budapesti Kereskedelmi és Iparkamara Hírközlési, Informatika osztályának állásfoglalása (A statement by the Communication and Informatics Section of the Budapest Chamber of Commerce and Industry) (2013) Retrieved from http://it.bkik.hu/hir/36-Kamarai-javaslat-onallo-Infokommunikacios-OPmagvalositasarol

Detschew, S. (2007) Impact of ICT in the Developing Countries on the Economic Growth, Auflage

Dobay P. (2011) A „Gazdaság-informatika” tantervek hazai gyakorlata és az EU keretrendszerei. „Business Information Systems” Curricula and the EU ICT Qualifications Frameworks, Retrieved from http://nodes.agr.unideb.hu/if2011/dokumentum/IF2011 CD Kiadvany.pdf

Fodor L. (2008) Az oktatás elmélete és metodológiája (The theory and methodology of the instruction process), Marosvásárhely

Kar-Tin Lee (2006) Online learning in primary schools: designing for school culture change, EMI, 43(2), pp. 91-106.

Kis-Tóth L (2008) A tanári tevékenység IKT alapelemei, (The ICT foundations of the teaching profession), 9. eLearning Fórum konferencia-kiadvány. SZÁMALK, Budapest, p. 3.

Kormányzati akcióterv az ikt-szektor támogatására (2009) (Governmental action plan for the support of the ICT sector) In: Prim Hírek, Retrieved from http://hirek.prim.hu/cikk/75453/

Krippendorff, K (1960) A tartalomelemzés módszertanának alapjai. (The methodological foundations of content analysis), Balassi, Budapest,

McCormack, A. (2010) The e-Skills Manifesto. A Call to Arms, ISBN 9789490477301, http://ec.europa.eu/enterprise/sectors/ict/files/e-skills manifesto en.pdf

Molnár György (2008) Az IKT-val támogatott tanulási környezet követelményei (Requirements of an ICT supported learning environment) Retrieved from http://www.mszt.iif.hu/documents/szsz0803molnar.pdf

Molnár György (2009) IKT, hálózati és mobil kommunikációs megoldások az atipikus tanulási formák tükrében. . (ICT, network, and mobile communcation solutions in light of atypical learning forms), 5. Magyar Nemzeti és Nemzetközi Lifelong Learning konferencia, Retrieved from http://www.mellearn.hu/events/5konf/prezentaciok/molnar_gyorgy.pdf, pp.3-4 
Nemzeti Fejlesztési Minisztérium, Kommunikációs Főosztály, Augusztus végéig véleményezhető a Nemzeti Infokommunikációs Stratégia (2013) (Ministry of National Development, Department of Communication National Info-communication Strategy, a document on which comments and observations can be made until August 2013) Retrieved from http://www.kormany.hu/

Nemzeti Infokommunikációs Stratégia 2014-2020. (2013) (National Info-communication Strategy) Retrieved from http://www.kormany.hu/

Nemzetközi összefogás az it-s szakemberhiány ellen. (International co-operation aimed at coping with a lack of professionals in the field of IT) Report by MTI (Hungarian Telegraph Office). (2013) Retrieved from http://www.itbusiness.hu/Fooldal/toplista/eb osszefogas szakemberhiany.html>

\section{AUTHOR AFFILATION \& ADDRESS}

Dr. Tünde Molnár Lengyel

Head of Department

Eszterhazy Karoly College

Institute of Media Informatics EKC, Eger, Hungary

Email: mtunde@ektf.hu 